\title{
Biological control of downy mildew of maize caused by Peronosclerospora sorghi under environmentally controlled conditions
}

\section{Y. Sireesha and R. Velazhahan*}

Department of Plant Pathology, Tamil Nadu Agricultural University, Coimbatore- 641003 (Tamil Nadu), INDIA

*Corresponding author. E-mail: velazhahan@hotmail.com

Received: June 12, 2015; Revised received: October 20, 2015; Accepted: February 25, 2016

\begin{abstract}
Downy mildew disease, caused by Peronosclerospora sorghi, is one of the most serious diseases of maize. The disease is currently managed by seed treatment with metalaxyl fungicides. However, problems regarding environmental pollution resulting from the use of fungicides and development of fungicide resistance within populations of $P$. sorghi are of increasing concern. Assuming that biological control by means of using antagonistic microorganisms may be an alternative for the management of this disease, the efficacy of biocontrol agents viz., Bacillus subtilis G1, Bacillus amyloliquefaciens B2, Brevibacillus brevis 57 and Pseudomonas fluorescens Pf1 for the management of downy mildew of maize and for promoting plant growth was evaluated. The results indicated that seed treatment with $B$. subtilis $\mathrm{G} 1$ and $B$. amyloliquefaciens $\mathrm{B} 2$ significantly $(P=0.05)$ increased the germination percentage and seedling vigour of maize as assessed by roll towel method. Among them, $B$. subtilis $\mathrm{G} 1$ was the most effective and recorded $9 \%$ and $31 \%$ increases in germination percentage and seedling vigour of maize respectively, as compared to the control. A talc- based powder formulation of $B$. subtilis $\mathrm{G} 1$ when applied through seed at the rate of $10 \mathrm{~g} / \mathrm{kg}$ reduced the downy mildew incidence up to $54 \%$ under greenhouse conditions. Results of this study suggest that $B$. subtilis $\mathrm{G} 1$ is a promising bioagent for the management of downy mildew of maize and for promoting plant growth. This antagonist could be further exploited for commercial scale up for ecofriendly management of downy mildew of maize under localized climatic conditions.
\end{abstract}

Keywords: Bacillus subtilis, Biocontrol, Downy mildew, Peronosclerospora sorghi, Zea mays

\section{INTRODUCTION}

Downy mildew, caused by Peronosclerospora sorghi (Weston \& Uppal) Shaw, is a disease of worldwide importance on maize (Zea mays L.) and sorghum [Sorghum bicolor (L.) Moench]. The fungus produces both local and systemic infection in both the crops (Bonman et al., 1983) and cause significant yield losses under favourable environmental conditions. Soil -borne oospores or aerially disseminated conidia cause systemic infection, whereas local infection is caused by conidia (Cohen and Sherman, 1977; Ramalingham and Rajasab, 1981; Bock et al., 1998). The local infection acts as a source of inoculum for subsequent systemic infection on young plants (Cohen and Sherman, 1977). This disease can occur at any stage of maize development from seedling to harvest, though it primarily infects soon after seedling emergence, until one month after planting. $P$. sorghi can cause significant yield losses under favourable environmental conditions and yields can be reduced up to $100 \%$ in susceptible cultivars depending on environmental conditions (Lukman et al., 2013). Genetic variabilities among isolates of $P$. sorghi have been reported (Bock et al., 2000; Perumal et al., 2006; Mathiyazhagan et al., 2008; Sireesha and Velazhahan, 2015). This disease is managed primarily with seed treatment with systemic fungicide, metalaxyl (Anahosur and Patil, 1980). But the use of synthetic chemical fungicides may pose threat to the environment by polluting the ecosystem. Further, the seed treatment with fungicides may not protect the crop for a longer period. The development of fungicide resistance within populations of $P$. sorghi has already been reported (Isakeit and Jaster, 2005). Although few resistant genotypes have been identified against this disease (Yen et al., 2004; Rashid et al., 2013), currently there are no commercially acceptable maize cultivars with adequate level of resistance to $P$. sorghi. Biological control method, by using naturally occurring non-pathogenic, antagonistic microorganisms has been considered as an environmentally safe and sustainable alternative to the use of synthetic chemical fungicides for the management of soil borne diseases. The applied antagonistic microorganisms can compete with the pathogen for nutrients, inhibit multiplication of pathogens by secreting antibiotics or lytic enzymes or reduce pathogen population through hyperparasitism. Sadoma et al. (2011) reported that crude culture filtrates of Trichoderma viride, T. harzianum, Gliocladium virens and Bacillus subtilis inhibited germination of oospores and conidia of $P$. sorghi. Further, the authors reported that seed soaking and spray treatment with crude culture 
filtrates of a combination of $T$. viride with $T$. harzianum or B. subtilis effectively reduced the incidence of downy mildew in maize under field conditions. Amin et al. (2013) demonstrated that seed treatment followed by soil application at 20 days after sowing with endophytic fungus Beauveria sp. effectively controlled downy mildew of maize. In this study, the efficacy of various bacterial antagonists viz., Bacillus subtilis G-1, Bacillus amyloliquefaciens B2, Brevibacillus brevis (Bbv) 57 and Pseudomonas fluorescens Pf1 selected based on previously determined antagonistic activity against other soilborne fungal pathogens (Meena et al., 2001; Shifa et al., 2015a) was assessed for suppression of downy mildew of maize caused by $P$. sorghi under environmentally controlled conditions. The aim of the present study was to find out the efficacy of biocontrol agents viz., Bacillus subtilis G1, Bacillus amyloliquefaciens B2, Brevibacillus brevis 57 and Pseudomonas fluorescens Pf1 for the management of downy mildew of maize and for promoting plant growth was evaluated.

\section{MATERIALS AND METHODS}

Bacterial cultures: The bacterial antagonists viz., $B a$ cillus subtilis G-1, Bacillus amyloliquefaciens B2, Brevibacillus brevis (Bbv) 57 and Pseudomonas fluorescens Pf1 were obtained from the Department of Plant Pathology, Tamil Nadu Agricultural University, Coimbatore, India. The cultures of Bacillus spp. were maintained on nutrient agar (NA) medium and P. fluorescens Pfl was maintained on King's medium B (KMB) (King et al., 1954) under laboratory conditions.

Seed germination and seedling growth bioassay: $B$. subtilis $\mathrm{G1}, B$. amyloliquefaciens, $B$. brevis were grown on nutrient broth and $P$. fluorescens Pf1 was grown on Kings' B broth with constant shaking at 150 rpm for $48 \mathrm{hrs}$ at room temperature $\left(26 \pm 2{ }^{\circ} \mathrm{C}\right)$. The bacterial cells were harvested by centrifugation at $6,000 \mathrm{rpm}$ for $15 \mathrm{~min}$ and the bacterial pellet was suspended in $0.01 \mathrm{M}$ phosphate buffer $(\mathrm{pH}$ 7.0). The final concentration of the suspension was adjusted to approximately $10^{8} \mathrm{CFU} / \mathrm{ml}\left(\mathrm{OD}_{595}=0.3\right)$ in a spectrophotometer (Thompson, 1996) and amended with $0.2 \%$ sterilized carboxymethyl cellulose (CMC) as a sticker. Maize seeds (cv. CM 500) were surface sterilized with $0.1 \%$ mercuric chloride for $5 \mathrm{~min}$ and rinsed thoroughly in sterile distilled water. The bacterization of seed was done by soaking surface sterilized maize seeds in bacterial suspensions@5 g/25 ml and incubating in a rotary shaker for $6 \mathrm{hrs}$ to facilitate attachment of bacterial cells to the seed coat. The seeds were then dried in shade for $2 \mathrm{hrs}$ and the plant growth promoting activity of the antagonists was assessed based on the seedling vigour following the standard roll towel method (International Seed Testing Association, 1996). The bacterized seeds were placed on coarse blotter paper sheets and covered with a moistened blot- ter and rolled. The roll was kept on a butter paper sheet and rolled as a bundle and incubated in a growth chamber at $25{ }^{\circ} \mathrm{C}$ with $80 \% \mathrm{RH}$. Four replications were maintained for each treatment. The root and shoot lengths of seedlings were measured and the germination percentage was calculated after 7 days. The vigour index was calculated as suggested by Baki and Anderson (1973).

Vigour index $=$ Per cent germination $\mathrm{x}$ seedling length (shoot length + root length)

Greenhouse experiments: The talc-based powder formulations of the antagonists were prepared by mixing $400 \mathrm{ml}$ of the bacterial suspension $\left(9 \times 10^{8} \mathrm{CFU}\right.$ $\mathrm{mL}^{-1}$ ) with $1 \mathrm{~kg}$ of sterilized talc powder amended with $10 \mathrm{~g}$ of carboxymethylcellulose under aseptic conditions (Vidhyasekaran and Muthamilan, 1995). Surfacesterilized maize seeds (cv. CM 500) were treated with talc formulation at a rate of $10 \mathrm{~g} / \mathrm{kg}$ of seed and sown in $30 \mathrm{~cm}$ diameter plastic pots filled with autoclaved soil and sand (2:1). Seeds mock-treated with the powder formulation without bacteria were kept as control. As a check, seeds were treated with Metalaxyl at $2 \mathrm{~g}$ $\mathrm{kg}^{-1}$ seed. Five seeds were sown in each pot and five pots were kept as one replication. The trial was conducted in a completely randomized design (CRD) with four replications.

In order to prepare pathogen inoculum, maize leaves showing symptoms of downy mildew were collected from the experimental farm of Tamil Nadu Agricultural University, Coimbatore, India. The infected leaves were wiped out with wet absorbent cotton, cut into small pieces of 4-5 cm lengths and placed with their abaxial side facing up in $9 \mathrm{~cm}$ diameter Petri dishes lined with wet filter paper on both the sides. The plates were incubated in the dark for 6-7 hrs at $20^{\circ} \mathrm{C}$ for sporulation (Narayana et al., 1995). Conidia were harvested from the surface of leaves by gently washing them into cold distilled water using a camel hair brush. The concentration of conidia was adjusted to $1 \times 10^{8}$ conidia $\mathrm{mL}^{-1}$ and used as inoculum. At two leaf stage, the seedlings were challenge inoculated by spraying with conidial suspension of $P$. sorghi $\left(4 \times 10^{4}\right.$ spores $\left.\mathrm{mL}^{-1}\right)$. The inoculated seedlings were maintained at $20 \pm 2^{\circ} \mathrm{C}$ temperature with $>95 \%$ relative humidity. At 30 days after sowing (DAS), plant height and percent disease incidence were measured. The inoculated plants were examined for leaf reaction 7 days after inoculation. Numerical values of 1,2 and 3 were assigned to resistant (R), intermediate (I) and susceptible (S) leaf reaction classes, respectively as described by Craig (1982).

Data analysis: Arc sine transformation of data on percentage of downy mildew incidence was done and. Duncan's multiple range test (DMRT) was first applied to the transformed values and then transferred to the original means (Gomez and Gomez, 1984). The data were analyzed using AgRes statistical software, version 3.01 (Pascal Int1 Software solutions). 


\section{RESULTS AND DISCUSSION}

In the present study the biocontrol agents viz., B. subtilis G1, B. amyloliquefaciens B2, B. brevis 57 and $P$. fluorescens Pf1 were tested for their plant growth promoting activity and efficacy in controlling downy mildew of maize under greenhouse conditions. The results indicated that seed treatment with $B$. subtilis $\mathrm{G} 1$ and B. amyloliquefaciens B2 significantly increased the percent germination and seedling vigour compared to control. Among the biocontrol agents, B. subtilis G1 recorded the maximum percent germination (96\%) and seedling vigour (4339.2) (Table 1; Fig. 1). However, the fungicide check Metalaxyl recorded the highest germination percentage (97\%) and seedling vigour (4573.5). Talc-based powder formulations of the biocontrol agents were prepared and evaluated under greenhouse conditions for their potential in the management of downy mildew of maize. The results indicated that all the tested antagonists significantly $(P=0.05)$ reduced the incidence of downy mildew compared to control (Table 2). Among the biocontrol agents tested, $B$. subtilis $\mathrm{G} 1$ was found to be the most effective in reducing the downy mildew disease when used as seed dresser@10 g/kg followed by $B$. amyloliquefaciens B2, B. brevis 57 and $P$. fluorescens Pfl. Seed treatment with the commercial fungicide Metalaxyl completely eliminated the development of downy mildew in maize seedlings.

Several strains of $B$. subtilis are widely used in agriculture as biopesticides for the management of plant diseases especially those caused by soil-borne plant pathogens (Jayaraj et al., 2005; Furuya et al., 2011; Yanez-Mendizabal et al., 2012; Hu et al., 2014; Khabbaz and Abbasi, 2014; Zhao et al., 2014). Bacillus spp. offer several advantages over other antagonistic microorganisms because they are capable of growing in different environmental conditions due to their ability to produce endospores that can tolerate extreme $\mathrm{pH}$, temperature, and osmotic conditions (Earl et al., 2008). Many B. subtilis strains when applied through seed bacterization rapidly colonize plant roots and suppress the growth of phytopathogens (Beauregard et al., 2013). The mechanisms of plant disease control by $B$. subtilis includes production of antibiotic substances (Stein 2005; Shifa et al., 2015b), production of cyclic lipopeptides like iturins, fengycins and surfactins (Ongena and Jacques, 2007), production of hydrolytic enzymes, including $\beta-1,4-N$-acetyl glucosaminidase (NAGase), chitinase and $\beta-1,3-$ glucanase (Manjula and Podile, 2005; Liu et al., 2011),

Table 1. Effect of seed treatment with biocontrol agents on seed germination and seedling vigour of maize.

\begin{tabular}{lcccc}
\hline Treatments & \% Germination* & Shoot length $(\mathbf{c m})$ & Root length $(\mathbf{c m})$ & Seedling vigour \\
\hline B. subtilis G1 & $96(78.5)^{\mathrm{a}}$ & $24.2^{\mathrm{a}}$ & $21.0^{\mathrm{a}}$ & $4339.2^{\mathrm{a}}$ \\
B. amyloliquefaciens $\mathrm{B} 2$ & $94(75.82)^{\mathrm{a}}$ & $23.9^{\mathrm{a}}$ & $20.3^{\mathrm{a}}$ & $4163.2^{\mathrm{a}}$ \\
Br. brevis (Bbv) 57 & $89(70.65)^{\mathrm{b}}$ & $22.6^{\mathrm{b}}$ & $19.7^{\mathrm{b}}$ & $3775.3^{\mathrm{b}}$ \\
P. fluorescens (Pf1) & $89(70.65)^{\mathrm{b}}$ & $20.7^{\mathrm{c}}$ & $18.2^{\mathrm{b}}$ & $3471.8^{\mathrm{b}}$ \\
Metalaxyl & $97(80.17)^{\mathrm{a}}$ & $23.9^{\mathrm{a}}$ & $20.3^{\mathrm{a}}$ & $4573.5^{\mathrm{a}}$ \\
Untreated Control & $88(69.73)^{\mathrm{b}}$ & $20.3^{\mathrm{c}}$ & $12.2^{\mathrm{c}}$ & $3307.0^{\mathrm{c}}$ \\
CD $(0.05)$ & 4.48 & 2.15 & 1.55 & 381.5 \\
\hline
\end{tabular}

The root and shoot lengths of seedlings were measured and the germination percentage was calculated 7 days after treatment; *Arc sine transformation of data was done prior to analysis; Four hundred seeds were used per treatment in four replications of 100 seeds each. The data are mean of four replications. Means within a column followed by a common letter are not significantly different $(P=0.05)$ by Duncan's multiple range test.

Table 2. Effect of seed treatment with talc based formulations of biocontrol agents on the incidence of downy mildew of maize under greenhouse conditions.

\begin{tabular}{|c|c|c|c|c|c|c|c|c|}
\hline \multirow[t]{2}{*}{ Treatment } & \multicolumn{3}{|c|}{$\begin{array}{l}\text { Number of leaves in } \\
\text { each reaction class }\end{array}$} & \multicolumn{3}{|c|}{$\begin{array}{l}\text { \% of leaves in } \\
\text { reaction class }\end{array}$} & \multirow[t]{2}{*}{$\begin{array}{l}\text { Mean leaf re- } \\
\text { action score }\end{array}$} & \multirow[t]{2}{*}{$\begin{array}{c}\% \text { disease inci- } \\
\text { dence }\end{array}$} \\
\hline & $\bar{R}$ & I & $\mathrm{S}$ & $\mathrm{R}$ & I & $\mathrm{S}$ & & \\
\hline Bacillus subtilis $\mathrm{G} 1$ & 40 & 23 & 17 & 50 & 29 & 21 & 1.7 & $46(42.71)^{b}$ \\
\hline Bacillus amyloliquefaciens B2 & 10 & 16 & 26 & 19 & 31 & 50 & 2.3 & $64(53.13)^{c}$ \\
\hline Brevibacillus brevis (Bbv) 57 & 8 & 22 & 38 & 12 & 32 & 56 & 2.4 & $69(56.17)^{\mathrm{c}}$ \\
\hline Pseudomonas fluorescens Pf1 & 16 & 18 & 24 & 28 & 31 & 41 & 2.1 & $73(58.69)^{d}$ \\
\hline Metalaxyl & 85 & 0 & 0 & 100 & 0 & 0 & 1.0 & $0(0.29)^{\mathrm{a}}$ \\
\hline Untreated Control & 7 & 16 & 35 & 12 & 28 & 60 & 2.5 & $100(89.72)^{\mathrm{e}}$ \\
\hline
\end{tabular}

The bacterial antagonists were applied as seed treatment $(10 \mathrm{~g} / \mathrm{kg})$ at the time of sowing. The bacterized plants were inoculated with $P$. sorghi at two leaf stage and the incidence of downy mildew was recorded 30 days after sowing;Numerical values of 1 , 2 , and 3 were assigned to resistant (R), intermediate (I) and susceptible (S) reactions respectively. A mean score was calculated for the leaf reactions of each treatment.;Data are mean of four replications;Data followed by the same letter in a column are not significantly different $(P=0.05)$ from each other according to DMRT. 


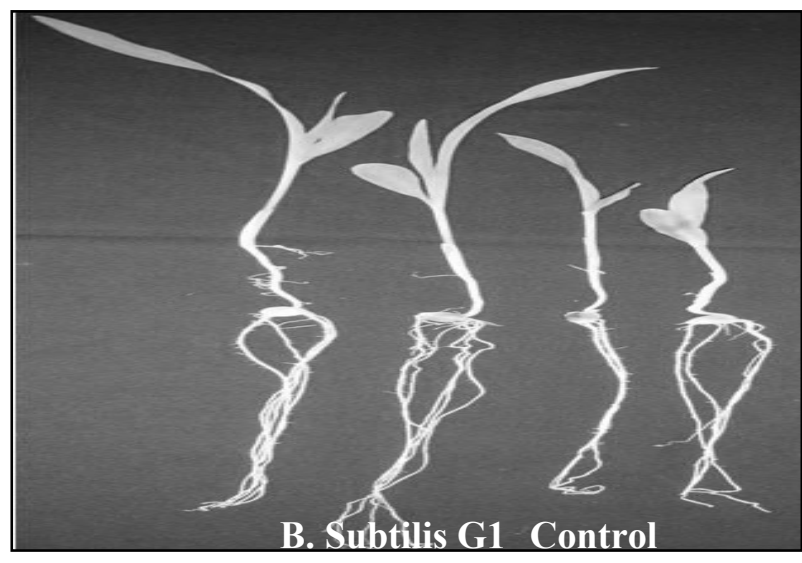

Fig. 1. Maize seedlings showing enhanced growth upon seed treatment with Bacillus subtilis G1.

which causes lysis of fungal cell walls and membranes and induction of systemic acquired resistance in plants (Choudhary and Johri, 2009; Lahlali et al., 2013; Sivasakthi et al., 2014). In addition to direct antagonistic activity against several soil borne fungal pathogens, B. subtilis is known to promote plant growth and yield (Kloepper et al., 2004; Perez-Garcia et al., 2011). The genome of B. subtilis strain BAB-1 has been fully sequenced and annotated and genes encoding the antifungal active compound have been identified in the genome (Guo et al., 2014). A number of commercial products based on B. subtilis including Kodiak (Gufstafson Biologicals, Plano, TX), Serenade (Agraquest Inc., Davis, CA), Subtilex (Becker Underwood, Ames, IA) have been developed for the control of various plant diseases (Schisler et al., 2004).

Shifa et al. (2015a) recently reported that seed treatment and soil application with the powder formulation of B. subtilis strain G1 effectively reduced the incidence of stem rot of groundnut caused by Sclerotium rolfsii and increased the pod yield. This strain was compatible with other beneficial rhizobacteria including Bacillus megaterium var phosphaticum strain PBS, Rhizobium strain BMBS, Azospirillum brasiliense strain 204 and Azotobacter chrooccocum strain AC1. Furthermore, production of 22 different kinds of antibiotics including aldehydes, fatty acids, alkanes, esters and sulphur containing compounds by this antagonistic strain was demonstrated (Shifa et al., 2015b). The increase in plant growth due to application of subtilis G1 in the present study may be due to plant growth promoting characteristics of $B$. subtilis G1 and the reduction in the incidence of downy mildew may be due to direct antagonistic activity of $B$. subtilis G1 against $P$. sorghi.

\section{Conclusion}

In the absence of downy mildew resistant maize cultivars, biological control by means of using antagonistic microorganisms will definitely reduce the environmental pollution and the cost of plant protection meas- ures. The results of this study suggest that B. subtilis G1 could be considered as a promising alternative to synthetic chemical fungicides in the management of maize downy mildew and could be successfully exploited as a biocontrol agent within the framework of integrated disease management system.

\section{ACKNOWLEDGEMENTS}

This study was supported by the INSPIRE Fellowship (Grant No.IF120724), Department of Science and Technology, Government of India, New Delhi to the first author.

\section{REFERENCES}

Amin, N., Daha, L., Nasruddin, A., Junaed, M. and Iqbal, A. (2013). The use of endophytic fungi as biopesticide against downy mildew Peronosclerospora spp. on maize. Acad. Res Int. 4: 153-159.

Anahosur, K. H. and Patil, S. H. (1980). Chemical control of sorghum downy mildew in India. Plant Dis. 64: 10041006.

Baki, A.A.A. and Anderson, J.D. (1973). Vigour determination in soy-bean seed by multiple criteria. Crop Sci. 31: 630-633.

Beauregard, P.B., Chai, Y., Vlamakis, H., Losick, R. and Kolter, R. (2013). Bacillus subtilis biofilm induction by plant polysaccharides. Proc. Natl. Acad. Sci USA 110: 1621-1630.

Bock, C.H., Jeger, M.J., Mughogho, L.K., Cardwell, K.F., Mtisi, E., Kaula, G. and Mukansabimana, D. (2000). Variability of Peronosclerospora sorghi isolates from different geographic locations and hosts in Africa. $M y$ col Res. 104: 61-68.

Bock, C.H., Jeger, M.J., Mughogho, L.K., Mtisi, E. and Cardwell, K.F. (1998). Production of conidia by Peronosclerospora sorghi on sorghum crops in Zimbabwe. Plant Pathol. 47: 243-251.

Bonman, J.M., Renfro, B.L. and Singburaudom, N. (1983). Correlation between resistance in maize to local and systemic infection by Peronosclerospora sorghi in Thailand. Plant Dis. 67: 219-220.

Choudhary, D.K. and Johri, B.N. (2009). Interactions of Bacillus spp. and plants with special reference to induced systemic resistance (ISR). Microbiol. Res. 164: 493-513.

Cohen, Y. and Sherman, Y. (1977). The role of airborne conidia in epiphytotics of Sclerospora sorghi on sweet corn. Phytopathology 67: 515-521.

Craig, J. (1982). Identification of sorghum downy mildew resistance in corn by leaf reaction to conidial inoculum. Phytopathology 72: 351-352.

Earl, A.M., Losick, R. and Kolter, R. (2008). Ecology and genomics of Bacillus subtilis. Trends Microbiol. 16: 269-275.

Furuya, S., Mochizuki, M., Aoki, Y., Kobayashi, H., Takayanagi, T., Shimizu, M. and Suzuki, S. (2011). Isolation and characterization of Bacillus subtilis KS1 for the biocontrol of grapevine fungal diseases. Biocontrol Sci. Technol. 21: 705-720.

Gomez, K.A. and Gomez, A.A. (1984). Statistical procedure for agricultural research. New York, USA.

Guo, Q., Li, S., Lu, X., Zhang, X., Wang, P. and Ma, P. 
(2014). Complete genome sequence of Bacillus subtilis BAB-1, a biocontrol agent for suppression of tomato gray mold. Genome Announc. 2(4):e00744-14.

Hu, X., Roberts, D.P., Xie, L., Maul, J.E., Yu, C., Li, Y., Jiang, M., Liao, X., Che, Z. and Liao, X. (2014). Formulations of Bacillus subtilis BY-2 suppress Sclerotinia sclerotiorum on oilseed rape in the field. Biol. Control 70: $54-64$.

International Seed Testing Association. (1996). International Rules for Seed Testing. Seed Sci. Technol. Supp. 24: 155-202.

Isakeit, T. and Jaster, J. (2005). Texas has a new pathotype of Peronosclerospora sorghi, the cause of sorghum downy mildew. Plant Dis. 89: 529.

Jayaraj, J., Radhakrishnan, N.V., Kannan, R., Sakthivel, K., Suganya, D., Venkatesan, S. and Velazhahan, R. (2005). Development of new formulations of Bacillus subtilis for management of tomato damping-off caused by Pythium aphanidermatum. Biocontrol Sci. Technol. 15: 55-65.

Khabbaz, S.E. and Abbasi, P.A. (2014). Isolation, characterization, and formulation of antagonistic bacteria for the management of seedlings damping-off and root rot disease of cucumber. Can. J. Microbiol. 60: 25-33.

King, E.O., Ward, M. K. and Raney, D. E. (1954). Two simple media for the demonstration of pyocyanine and fluorescein. J. Lab. Clin. Med. 44: 301-307.

Kloepper, J.W., Ryu, C.M. and Zhang, S. (2004). Induced systemic resistance and promotion of plant growth by Bacillus spp. Phytopathology 94: 1259-1266.

Lahlali, R., Peng, G., Gossen, B.D., McGregor, L., Yu, F.Q., Hynes, R.K., Hwang, S.F., McDonald, M.R. and Boyetchko, S.M. (2013). Evidence that the biofungicide Serenade (Bacillus subtilis) suppresses clubroot on canola via antibiosis and induced host resistance. Phytopathology 103: 245-254.

Liu, Y., Tao, J., Yan, Y., Li, B., Li, H. and Li, C. (2011). Biocontrol efficiency of Bacillus subtilis SL-13 and characterization of an antifungal chitinase. Chin. J. Chem. Eng. 19: 128-134.

Lukman, R., Afifuddin, A. and Lubberstedt, T. (2013). Unraveling the genetic diversity of maize downy mildew in Indonesia. J. Plant Pathol. Microb. 4: 162.

Manjula, K. and Podile, A.R. (2005). Production of fungal cell wall degrading enzymes by a biocontrol strain of Bacillus subtilis AF1. Ind. J. Exp. Bot. 43: 892-896.

Mathiyazhagan, S., Karthikeyan, M., Sandosskumar, R. and Velazhahan, R. (2008). Analysis of variability among the isolates of Peronosclerospora sorghi from sorghum and corn based on restriction fragment length polymorphism of ITS region of ribosomal DNA. Arch. Phytopathol. Plant Protect. 41: 231-237.

Meena, B., Marimuthu, T., Vidyasekaran, P. and Velazhahan, R. (2001). Biological control of root rot of groundnut with antagonistic Pseudomonas fluorescens strains. J. Plant Dis. Protect. 108: 368-381.

Narayana, Y.D., Mughogho, L.K. and Bandyopadhyay, R. (1995). Evaluation of greenhouse inoculation techniques to screen sorghum for resistance to downy mildew. Euphytica 86: 49-53.

Ongena, M. and Jacques, P. (2008). Bacillus lipopeptides: versatile weapons for plant disease control. Trends $\mathrm{Mi}$ crobiol 16: 115-125.

Perez-Garcia, A., Romero, D., De Vicente, A. (2011). Plant protection and growth stimulation by microorganisms: biotechnological applications of Bacilli in agriculture. Curr. Opin. Biotech. 22: 187-193.

Perumal, R., Isakeit, T., Menz, M., Katile, S., No, E.G. and Magill, C.W. (2006). Characterization and genetic distance analysis of isolates of Peronosclerospora sorghi using AFLP fingerprinting. Mycol. Res. 110: 471-78.

Ramalingham, A. and Rajasab, A.H. (1981). Epidemiology of sorghum downy mildew. VI. Relative importance of oospores and conidia in epidemics of systemic infection. Proc. Indian Nat. Sci. Acad. Part B 47: 625-630.

Rashid, Z., Zaidi, P. H., Vinavan, M. T., Sharma, S. S. and Srirama Setty, T. A. (2013). Downy mildew resistance in maize (Zea mays L.) across Peronosclerospora species in lowland tropical Asia. Crop Prot. 43: 183-191.

Sadoma, M.T, El-Sayed, A.B.B. and El-Moghazy, S.M. (2011). Biological control of downy mildew disease of maize caused by Peronosclerospora sorghi using certain biocontrol agents alone or in combination. J. Agric. Res. Kafer El-Sheikh Univ. 37 (1): 1-11.

Schisler, D.A., Slininger, P.J., Behle, R.W. and Jackson, M.A. (2004). Formulation of Bacillus spp. for biological control of plant diseases. Phytopathology 94: 1267-1271.

Shifa. H., Gopalakrishnan, C. and Velazhahan R. (2015a). Efficacy of Bacillus subtilis G-1 in suppression of stem rot caused by Sclerotium Rolfsii and growth promotion of groundnut. International Journal of Agriculture, Environment and Biotechnology. 8(1): 111-118.

Shifa. H., Gopalakrishnan, C. and Velazhahan R. (2015b). Characterisation of antifungal antibiotics produced by Bacillus subtilis G-1 antagonistic to Sclerotium rolfsii. Biochem. Cell. Archives. 15(1): 99-104.

Sireesha, Y. and Velazhahan, R. (2015). Assessing genetic diversity in Peronosclerospora sorghi causing downy mildew on maize and sorghum. Indian Phytopath. 68 (1): 73-77.

Sivasakthi, S., Usharani, G. and Saranraj, P. (2014). Biocontrol potentiality of plant growth promoting bacteria (PGPR)- Pseudomonas fluorescens and Bacillus subtilis: A review. African J. Agric. Res. 9: 1265-1277.

Stein, T. (2005). Bacillus subtilis antibiotics: structures, syntheses and specific functions. Mol. Microbiol. 56: 845-857.

Thompson, D.C. (1996). Evaluation of bacterial antagonist for re-duction of summer patch symptoms in Kentucky blue grass. Plant Dis. 80: 856-862.

Vidhyasekaran, P. and Muthamilan, M. (1995). Development of formulations of Pseudomonas fluorescens for control of chickpea wilt. Plant Dis. 79: 782-786.

Yanez-Mendizabal, V., Vinas, I., Usall, J., Torres, R., Solsona, C., Abadias, M. and Teixido, N. (2012). Formulation development of the biocontrol agent Bacillus subtilis strain CPA-8 by spray-drying. J. Appl. Microbiol. 112: 954-965.

Yen, T.T.O., Prasanna, B.M., Setty, T.A.S. and Rathore, R.S. (2004). Genetic variability for resistance to sorghum downy mildew (Peronosclerospora sorghi) and Rajasthan downy mildew ( $P$. heteropogoni) in the tropical/subtropical Asian maize germplasm. Euphytica. 138: 23-31.

Zhao, P., Quan, C., Wang, Y., Wang, J. and Fan, S. (2014). Bacillus amyloliquefaciens Q-426 as a potential biocontrol agent against Fusarium oxysporum f. sp. spinaciae. J. Basic Microbiol. 54: 448-456. 